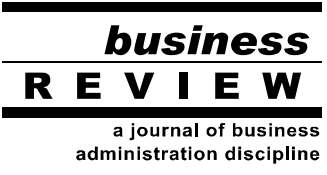

\section{Board Composition, Insider Ownership and Firm Performance: Evidence from Post-Shock Period of Stock Prices in Bangladesh}

\author{
Md. Faruk Hossain ${ }^{l}$
}

Keywords: Board Composition, Insider ownership, Endogeneity, Agency Theory, Corporate Governance, Bangladesh.

\title{
Introduction
}

The corporate governance practice facilitates a firm to maximize the shareholders' wealth through controlling for agency problem. But, how properly corporate governance works in a corporation probably depends on the board composition. According to Rose (2005), the board of directors drives a leading role in keeping a close sight of supervision on managers' activities that makes the managers more reluctant to create agency problem. This is Brennan (2006) who properly justified the statement that board is primarily responsible to monitor and supervise the managers' activities and formulate the strategic guidelines. But to find a structure of a board best fitting with corporate goals generates much debate concentrated on some fundamental questions. Firstly, is a large board beneficial to firm performance? In developing the significance of this question, it can be argued that a small size corporate board is desirable in order to ensure an effective management and control. In addition, though a large size board initially facilitates key board functions, there might remain suffering from board coordination and communication problems that leaves the managers relatively free to take over the control of the firm opportunistically and, therefore, board effectiveness and firm performance decline (Jensen, 1993; Hermalin and Weisbach, 2003). But the findings of Coles et al. (2008) confirmed that value of larger firms is significantly and positively associated with the board size, whereas a large board is not proved beneficial to the smaller firms for the progress of their value. Secondly, at what extent board independence (ratio of outside independent directors to total directors) is equitable to protect the shareholders' best interests? It is important, in response to this question, to open a view that the absence of independent directors in a board provides the Chief Executive Officer (CEO) enormous

\footnotetext{
${ }^{1}$ Associate Professor, Department of Business Administration, Hamdard University Bangladesh, Email: faruk_par_fin@yahoo.com
} 
Business Review- A Journal of Business Administration Discipline, Khulna University, Volume: 15, Number: 1, January-December 2020, pp. 1-13 (Print ISSN: 1811-3788; Online ISSN: 2664-3502)

dominating and controlling power over the board and, resultantly, the board could severely be inundated with conflicts of interests (Weidenbaum, 1986). In contrast, it is argued by Donaldson and Davis (1991) that inside directors are closely tied to the company, and they understand, supervise, and monitor the business effectually compared to the outside directors. Thirdly, is CEO duality really detrimental to the performance of the company? In the context of board leadership structure, it is a situation where the CEO simultaneously holds the chairperson of the board. In viewing of this question, Donaldson and Davis (1991) claimed that, "The executive manager, under this theory, far from being an opportunistic shirker, essentially wants to do a good job, to be a good steward of the corporate assets". In contrast, there is a view opined by Dayton (1984) that the space of supervising and controlling ability of the board shrinks if CEO duality exist, resultantly firm performance deteriorates.

In an attempt at protecting the interests of investors and capital markets through the mechanisms of corporate governance practicing, Bangladesh Securities Exchange Commission (BSEC) issued, the first time of the history of Bangladesh, a Corporate Governance Notification (CGN) to all listed companies in 2006 as "comply or explain" basis. It required the companies, among other requirements, to have a corporate board having a minimum number of 5 and a maximum number of 20 directors including 10 percent independent directors of the board members, but at least one independent director. Incorporation of this guideline into the corporation level necessarily yielded a hope against hope that company could be directed and controlled in such a way so that investors' right could be protected. But shockingly, the benchmark index of Dhaka Stock Exchange (DSE) reached 4000 points in 2010 for the first time in her history and crossed 8500 points in the same year. Thereafter, following a dramatic downturn it abruptly reached at around 5,500 points in October 2011. Apart from, founding sponsors/directors started grabbing the opportunity of making high capital gain through selling their shares. And BSEC issued a directive mandatory in November, 2011 urging the board directors to maintain a minimum of 30 percent ownership together so that this substantial insider ownership can curb the market from a large plunge in loss. In line with this perception, the study developed the final question- whether insider ownership leads to a better corporate performance.

However, in the aftermath of this shock, many more retail investors lost their last resorts. Thereafter, a heated debate started revolving around the necessity of further modifications, specially, in regard to the policy deserving more board independence. Along this line, in an empirical analysis in Bangladesh, Rashid et al. (2010) found that the current setting of board structure does not provide the independent directors with supervisory position and, resultantly, they become unable to see beyond their narrow space and to increase the economic value of firm. However, in order to ensure the healthy contribution of independent-outside directors in the board, consistent with international corporate governance code, the BSEC formulated a revised CGN in 2012 that requires the listed companies in DSE to increase the minimum ratio of outside-independent directors to total board members to 20 percent from 10 percent; it replaced the CGN in 2006 with CGN in 2012. This modification was made with an objective to ensure the establishment of a balanced board in all corporate levels that can drive them to control for the agency problems. In the light of this situation, Bangladesh is keeping good pace with the world development in the corporate governance practices for reaping the best outcomes.

However, there is very little evidence to investigate the effect of board structure and insider ownership on firm performance in Bangladesh - more specifically, the evidence drawn from the period of issuing a reformed corporate governance notification (CGN 2012) followed by a great shock of equity share prices in Bangladesh. Therefore, the objective of this study is designed to investigate the influence of board structure and insider ownership on corporate performance in Bangladesh.

\section{Literature Review and Hypothesis Development}

The path of ensuring the role of board composition and insiders' equity holdings in maximizing firm performance is still a debating issue led by different theories in corporate governance, which is further evident by the empirical results. This study endeavors penetrating earlier studies in order to develop the hypothesis and to explore a clear implication of these issues. 
Business Review- A Journal of Business Administration Discipline, Khulna University, Volume: 15, Number: 1, January-December 2020, pp. 1-13 (Print ISSN: 1811-3788; Online ISSN: 2664-3502)

\section{Independent Variables}

Board size: The board of a corporation has the responsibility to formulate business strategy and policy and oversee the management's activities for achieving corporation's goals. A board is accountable to protect the investors' interests. But how collectively the board is functioning and how equally the board is thinking in satisfying stakeholders' interests and attaining corporate goal with minimal agency problem could depend on the board size as it is a collection of individuals from diversified backgrounds bearing various talents, qualifications, knowledge, and skills.

According to the arguments of stewardship theory, agents (managers) are not self-motivated rather motivated by the interest of their principals (owners) and the extent of this motivation could be subject to the quality of the relationship between them (Davis et al. 1997). Therefore, a smaller number of people in a board might be justified to review the management actions and this in turn may lead to enhance the firm performance. Yermack (1996) confirms that board size and firm value are negatively related, supporting a view that large board experiences poor coordination, cumbersome communication, and asymmetric information and thus the costs of this type board outstrip its benefits.

Agency theory (Jensen and Meckling, 1976) argues that a large board is desirable for minimizing the agency problems since a large board is a collection of greater number of people that can ensure a wide range supervision, review, and monitor over the managerial actions seamlessly. Zahra and Pearce (1989) argue that boards comprises of more than average directors experience better performance and favor company in gaining competitive edge and eliminating harmful externalities. According to Preffer (1987), larger board gives the firm a well-diversified board having non-executive and executive directors that helps the firm to procure critical resources and protect from any internal and external environmental threats. In the same vain, Forbes and Milliken (1999) document that larger board retains a high quality decision-making power and be expedient to the firm if they get a run of unanimity. Kiel and Nicholson (2003), Kalsie and Shrivastav (2016) and Karayel and Doğan (2016) find a positive relation between board size and firm performance. Thus, following the agency theory this study proposes a hypothesis that large board is advantageous to firms to enhance their performance.

Board independence: As per views of the agency theory, independent directors intensifies board efficacy in supervising and monitoring management activities because they are outsiders, less beholden to family directors, not controlled by the executives, and bear advance qualifications, expertise and experience (Fields \& Keys, 2003) and they assist the company to be on a drive of effective board decisions and prosperity. Along this line, Liu et al. (2015) and Al-Msiedeen et al. (2018) find a positive impact of board independence on firm performance. In contrast, the advocates of stewardship theory argue that a board featuring substantial size of inside directors experiences better performance in maximizing shareholders' wealth compared to the board occupying outside independent directors (Donaldson, 1990; Donaldson and Davis, 1991) because outsiders mostly suffer from lack of firm-inside information (Adams and Ferreira, 2007). Along the line, Brennan (2006) claims that independent directors are parttimers and have less incentive to dig dipper into the company inside information and, therefore, they fail to bring desired outcome of the stakeholders.

Empirical results show inconclusive evidence on the relationship between these variables. In an instance, the findings of Daily and Dalton (1992) approved a positive relationship; Bhagat and Black (2002) confirmed a negative relationship; while Hermalin and Weisbach (1991) observed no relationship. As it has been mentioned earlier that one of the major modifications brought in the CGN in 2012 by the BSEC attempts to enhance the scope of good governance practicing in Bangladesh through extending the requirement of the minimum ratio of independent directors in to total directors of board to 20 percent. Therefore, pondering the agency theory this study postulates that board independence is advantageous to the firms to enhance their performance.

CEO duality: This is a situation when the position of the chairman of a board and the position of CEO are occupied by the same person. The responsibility of a board of directors verily encompasses the following areas: supervising executive activities, delegating work to CEO, and procuring external assets required to boost corporate performance (Johnson et al., 1996). Apart from, it is the board's responsibility to fulfill the legitimate claims of corporate entity- 
Business Review- A Journal of Business Administration Discipline, Khulna University, Volume: 15, Number: 1, January-December 2020, pp. 1-13 (Print ISSN: 1811-3788; Online ISSN: 2664-3502)

more specifically, shareholders' claims. But the leadership and professional skill of the Chairperson make a good influence on how effectively the board is supervising the work of the managers for the fulfillment of the shareholders' interest (Leblanc, 2004). The advocates of stewardship theory claim that duality is not detrimental to the betterment of company performance as it provides unity of command and eliminates any conflict-at-interest between executives and non-executives. Empirical research finds that the firms having CEO duality experiences better performance in maximizing shareholders' wealth (Donaldson and Davis, 1991).

On the opposite end of the spectrum, agency theory (Fama and Jensen, 1983) claims that a person occupying two hats (duality) enjoys a big incentive to wield power and authority in fulfilling personal interest rather than company's broad welfares; it also exposures to an unbalanced power in the board (Tricker, 1994). In addition, a board with duality is typically over controlled by the executives; it threatens the good governance practices in the corporation (Tricker, 1994; Yermack, 1996). Empirical evidence (such as Daily and Dalton, 1994; Carter et al., 2003; Doğan et al., 2013; Blibech and Berraies, 2018) confirms the detrimental impact of duality on corporate performance. Consistent with the agency theory, this study hypothesizes that CEO duality is not advantageous to the firms to enhance their performance.

Insider ownership: Insider ownership, as a proxy of managerial ownership, seems to be acting as a governance tool in aligning the managerial interests with shareholder interests (Jensen and Meckling, 1976). Therefore, if a substantial stake of company ownership is held by the managers, they would be incentivized as well as motivated to work for maximizing their performance and eventually it would enhance firm performance. Empirical analyses (such as Han and Suk, 1998; Mollah and Talukder, 2007; Lima and Hossain, 2018) reached at the findings similar to this inference. In contrast, it might yield additional costs and deteriorate firm performance due to the effects of managerial entrenchment (Fama and Jensen, 1983). Thus, holding a high level of ownership by insiders yields enormous power and congests the space of good governance in the board which, in turn, incentivizes them to pursue their own interests. In the same vein, Hasan and Butt (2009) and Wahla et al. (2012) find a negative association between them.

The sphere of equity ownership in Bangladeshi listed companies is highly dominated by family members (Rashid and Lodh, 2008) that cause an insider ownership. Therefore, to check the impact of insider ownership on firm performance the study measures it by the percentage of shares held by the directors of board following the work of Rashid (2015).

After stock market crush, the BSEC issued a directive in regard to holding a minimum of $30 \%$ shares by sponsors, promoters and directors with a view of increasing insider ownership to put a curb on market plunge in loss. Thus, it is assumed that compliance with this principal could bring the directors into a state of concentrated ownership and their investments would be robustly tied up to the firm performance that put them off making expropriation of firm assets. Hence, they don't find any incentives to steal their own money and become more accountable to practicing good corporate governance. Taking into account the directive of BSEC, the study develops a hypothesis that insider ownership is advantageous to the firms to enhance their performance.

\section{Control Variables}

Being parallel to the extant studies (Han and Suk, 1998; Wan and Ong, 2005; Rashid, 2009; Rashid et al., 2010), five control variables (total debt to total shareholders' equity, total long term debt to total shareholders' equity, growth, age, industry dummy) are used in this study in order to avoid any spurious association between dependent and independent variables.

\section{Dependent Variables}

The study employs firm financial performance as dependent variables which are defined by the three performance measures: Return on Assets (ROA) and Return on Equity (ROE) under accounting performance measures; and Tobin's Q (TBQ) under a market based performance measure. 
Business Review- A Journal of Business Administration Discipline, Khulna University, Volume: 15, Number: 1, January-December 2020, pp. 1-13 (Print ISSN: 1811-3788; Online ISSN: 2664-3502)

\section{Research Design}

Collection of data: The sample of the study is 45 listed companies which have been drawn from 204 nonfinancial companies listed on Dhaka Stock Exchange (DSE) in 2018. The sample represents the eight industries of fourteen different industries namely Cement, Ceramics, Engineering, Food and Allied, Fuel and Power, Information Technology (IT), Pharmaceuticals and Chemicals, and Textile. Based on availability of the annual reports (in electronic-format) over the study period ranging from 2013 to 2018 this study has chosen its sample. Thus, the study has left six industries that include only 21 companies representing a very poor amount $(10 \%)$ in the total population. The majority of the data used in the study are obtained from the annual reports of the sample firms but the market value of stock is gathered from the library of Dhaka Stock Exchange (DSE). In this context, this study includes 270 observations for 45 companies and 6 time periods; this size is almost equal to the total observations of Rashid et al. (2010). Therefore, it is argued that the sample can represent the population.

Data analysis procedures and model specification: To attain the objective, this study used a balanced pooled data, which has the ability to provide "more informative data, more variability, less collinearity among variables, and more efficiency" (Baltagi, 1995). In analyzing the data, the study has gone through both descriptive and econometric processes. However, the following functional form of econometric model was designed to test the hypotheses.

Performance $_{\mathrm{it}}=\alpha+\beta_{1}(\mathrm{LNBS})_{\mathrm{it}}+\beta_{2}(\mathrm{BIND})_{\mathrm{it}}+\beta_{3}(\mathrm{CEOD})_{\mathrm{it}}+\beta_{4}(\mathrm{IOWN})_{\mathrm{it}}+\beta_{5}(\mathrm{DE})_{\mathrm{it}}+\beta_{6}(\mathrm{TDE})_{\mathrm{it}}+\beta_{7}(\mathrm{AGE})_{\mathrm{it}}+$ $\beta_{8}(\mathrm{GROW})_{\mathrm{it}}+\beta_{9}(\text { INDUM1 })_{\mathrm{it}}+\beta_{10}(\text { INDUM2 })_{\mathrm{it}}+\beta_{11}(\text { INDUM3 })_{\mathrm{it}}+\beta_{12}(\text { INDUM4 })_{\mathrm{it}}+$ $\beta_{13}(\text { INDUM5) })_{i t}+\beta_{14}(\text { INDUM6) })_{i t}+\beta_{15}(\text { INDUM7) })_{i t}+\varepsilon_{i t}$

Where:

\begin{tabular}{|c|c|c|c|c|}
\hline \multicolumn{2}{|c|}{ Variables } & Proxies & Symbol & Measures \\
\hline 를 & $\begin{array}{c}\text { Firm } \\
\text { Performance }\end{array}$ & $\begin{array}{l}\text { Return on Assets } \\
\text { Return on Equity } \\
\text { Proxy of Tobin's Q }\end{array}$ & $\begin{array}{l}\text { ROA } \\
\text { ROE } \\
\text { TBQ }\end{array}$ & $\begin{array}{c}\text { Earnings before interest and taxes } \div \text { Total assets } \\
\text { Earnings before interest and taxes } \div \text { Shareholders' equity } \\
\text { (Market value of common equity }+ \text { Total liabilities }) \div \text { Book } \\
\text { value of total Assets }\end{array}$ \\
\hline \multirow[b]{2}{*}{ 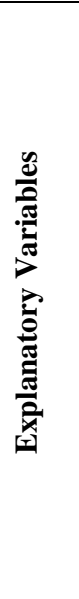 } & $\begin{array}{c}\text { Independent } \\
\text { Variables }\end{array}$ & $\begin{array}{c}\text { Board Size } \\
\text { Board Independence } \\
\text { CEO Duality } \\
\text { Insider Ownership }\end{array}$ & $\begin{array}{l}\text { LNBS } \\
\text { BIND } \\
\text { CEOD } \\
\text { IOWN }\end{array}$ & $\begin{array}{l}\text { Natural logarithm of the total number of members on the board } \\
\text { Proportion of independent director on the board } \\
\text { ' } 1 \text { ' if CEO duality exists, ' } 0 \text { ' otherwise } \\
\text { Proportion of shares held by directors/sponsors }\end{array}$ \\
\hline & $\begin{array}{c}\text { Control } \\
\text { Variables }\end{array}$ & $\begin{array}{l}\text { Leverage-1 } \\
\text { Leverage-2 } \\
\text { Firm Age } \\
\text { Firm Growth } \\
\text { Industry dummy } \\
\text { Industry dummy } \\
\text { Industry dummy } \\
\text { Industry dummy } \\
\text { Industry dummy } \\
\text { Industry dummy } \\
\text { Industry dummy }\end{array}$ & $\begin{array}{l}\text { DE } \\
\text { TDE } \\
\text { AGE } \\
\text { GROW } \\
\text { INDUM1 } \\
\text { INDUM2 } \\
\text { INDUM3 } \\
\text { INDUM4 } \\
\text { INDUM5 } \\
\text { INDUM6 } \\
\text { INDUM7 }\end{array}$ & $\begin{array}{l}\text { Long term liabilities } \div \text { Shareholders' equity } \\
\text { Total liabilities } \div \text { Shareholders' equity } \\
\text { Total no. of years since the firm was listed on the DSE } \\
\text { Relative } \Delta \text { in book value of total assets } \\
\text { ' } 1 \text { ' if the observation belongs to Ceramics, '0' otherwise } \\
\text { ' } 1 \text { ' if the observation belongs to Engineering, ' } 0 \text { ' otherwise } \\
\text { ' } 1 \text { ' if the observation belongs to Food \& Allied, ' } 0 \text { ' otherwise } \\
\text { ' } 1 \text { ' if the observation belongs to Fuel \& Power, ' } 0 \text { ' otherwise. } \\
\text { ' } 1 \text { ' if the observation belongs to IT, ' } 0 \text { ' otherwise } \\
\text { ' } 1 \text { ' if the observation belongs to Pharmaceuticals \& } \\
\text { Chemicals, ' } 0 \text { ' otherwise } \\
\text { ' } 1 \text { ' if the observation belongs to Textile, ' } 0 \text { ' otherwise }\end{array}$ \\
\hline
\end{tabular}

Empirical evidences such as Hermalin and Weisbach (2003) and Bhagat and Black (2002) suggest that there might be a danger of endogeneity problem inherent in the relationship between board, ownership, and performance. And it shall be a great concern while a study runs a regression of Ordinary Least Square (OLS) model. It is because the OLS coefficients would be no more consistent and unbiased if the variables suffer from endogenous problems. To insulate the regression coefficients from the damaging effects of endogeneity, simultaneous equation technique like two-stage least square (2SLS) regression is preferable. Thus, this study has also used 2SLS in examining their relationship. Moreover, to check whether OLS model is statistically and significantly better than 2SLS model a Hausman test (Greene, 2003) is employed. And, to investigate any possible existence of multicollinearity among the 
Business Review- A Journal of Business Administration Discipline, Khulna University, Volume: 15, Number: 1, January-December 2020, pp. 1-13 (Print ISSN: 1811-3788; Online ISSN: 2664-3502)

regressors a Variance Inflation Factor (VIF) has been used. Using STATA version 14.0 for windows, all these analyses are calculated.

Choosing instruments for endogenous variable: It is necessary to make sure that there endogeneity issue really exists in the relationship between structure of corporate board and performance of corporation. This study assumes that the structure of corporate board, more specifically board size, is endogenous. So, to check this problem, this study employed the Durbin and Wu-Hausman tests for endogeneity with a null hypothesis that board size is exogenous variable in influencing performance of the firm. Endogeneity can be controlled by taking instrumental variables in a regression. But choosing good instrumental variables is mostly arbitrary and mostly depends on variables availability in the area of interest literature. In identifying the instrumental variables of board size, Agrawal and Knoeber (1999) claimed that board structure is influenced by the industry settings and also firm ownership structure. According to Fama and Jensen (1983) a firm with high executive ownership may face a conflict of interest between non-executive and executive directors because when holding excessive ownership by managers incentivize them to ride on their personal interest at the cost of dispersed owners. Hence, to mitigate this conflict board has to be larger in size requiring more independent directors. In this regard, Coles et al. (2008) argue that board size is related to the firm specific variables, such as Tobin's Q, profitability and firm size.

Table 1: Description of instrumental variables

\begin{tabular}{cc}
\hline Instrumental Variables & Measures \\
\hline Firm Size (Lns) & Natural logarithm of total sales \\
Executive Ownership (Eown) & $\%$ of ownership held by executives \\
Debt Ratio (Tdta) & Total liabilities $\div$ Total assets \\
\hline
\end{tabular}

Moreover, Pfeffer (1972) claims if a firm requires more external source of fund like debt finance then the firm has to increase its board size. In the same vein, Booth and Deli (1996) claimed that a large-sized firm has to establish high external network, and, therefore, may prefer larger boards. Based on these arguments, to control endogeneity of board size this study also takes into account firm size and debt ratio. Thus, this study applied firm size, executive ownership, and debt ratio as instrumental variables. Apart from, for checking the validity of the identified instruments, over-identification test is applied. Description of these variables is presented in Table 1.

\section{Results and Discussions}

Descriptive statistics: The mean value of firm performance is: $10.82 \%$ with a range from $-4.53 \%$ to $52.20 \%$ under a performance measure of ROA, which is high compared to the result (5.7\%) found by Rashid et al. (2010) during 2005-2009; $20.45 \%$ ranging from $-6.64 \%$ to $106.77 \%$ under a performance measure of ROE; and 1.5319 ranging from 0.1953 to 8.9629 under TBQ performance measure, which is high in comparison with the result (1.29) found by Rashid et al. (2010) implying that after a great shock the market has recovered investors' confidence and come back to its normal behavior.

Table 2: Summary of Descriptive Statistics

\begin{tabular}{ccccc}
\hline Variable & Mean & Std. Dev. & Minimum & Maximum \\
\hline ROA & 0.1082 & 0.0908 & -0.0453 & 0.5220 \\
ROE & 0.2045 & 0.1930 & -0.0664 & 1.0677 \\
TBQ & 1.5319 & 1.2464 & 0.1953 & 8.9629 \\
LnBrd & 1.999 & 0.3027 & 1.61 & 3 \\
Indr & 0.2086 & 0.0764 & 0.05 & 0.63 \\
Dual & 0.0630 & 0.2433 & 0 & 1 \\
InOwn & 0.4754 & 0.2014 & 0.0476 & 0.9 \\
Lev1 & 0.2425 & 0.4366 & 0 & 2.6875 \\
Lev2 & 0.9998 & 0.9557 & 0.0312 & 6.4074 \\
Grow & 0.1510 & 0.2648 & -0.1471 & 3.0989 \\
Age & 19.53 & 11.0267 & 7 & 41 \\
\hline
\end{tabular}


Business Review- A Journal of Business Administration Discipline, Khulna University, Volume: 15, Number: 1, January-December 2020, pp. 1-13 (Print ISSN: 1811-3788; Online ISSN: 2664-3502)

Inspection of Table 2 also reveals that every firm in the study has a board consisting of an average number of 7.7481 directors. In most firms, chairperson of a board and chief executive are not belonging to the same person as it has a mean value of $6.3 \%$ indicating a good compliance with corporate governance notifications (CGN 2012) in Bangladesh; it was 29.66\% during 2006-2011 (Rashid, 2015). As seen from Table 2, on an average the corporate board is led by $20.86 \%$ independent directors varying between $5 \%$ and $63 \%$ implying a good compliance with the amended notification of BSEC; it was $11.26 \%$ over 2006-2011 (Rashid, 2015). The mean of insider shareholdings is $47.54 \%$ with a minimum of $4.76 \%$ and a maximum of $90 \%$, which is higher than that of earlier results in Bangladesh (40.36\% reported in Rashid, 2015). The average value of leverage is: $24.25 \%$ ranging from 0 to $268.75 \%$ is for Lev1; and $99.98 \%$ ranging from $3.12 \%$ to $640.74 \%$ is for Lev2 indicating that the firms are using almost BDT50 of debt for financing each BDT100 of assets. The mean value of age and growth of the firms are $26.48 \%$ and $15.10 \%$ respectively.

Multicollinearity: The variance inflation factor (VIF) is performed in order to identify the presence of multicollinearity in the sample variables. Table 3 shows no evidence of a severe multicollinearity among regressors. There is rule of thumb in the literature that the value of VIF less beyond 10 indicates multicollinearity (Chaterjee and Price, 1991).

Table 3: Summary of VIF for Regressors

\begin{tabular}{ccc}
\hline Variable & VIF & 1/VIF \\
\hline Lev2 & 1.77 & 0.564974 \\
Lev1 & 1.69 & 0.592080 \\
LnBrd & 1.28 & 0.781353 \\
InOwn & 1.24 & 0.805655 \\
Age & 1.09 & 0.919042 \\
Dual & 1.08 & 0.921752 \\
Indr & 1.07 & 0.935658 \\
Grow & 1.05 & 0.951747 \\
\hline
\end{tabular}

Results of endogeneity, overidentification, and hausman tests: This study initially attempted to use OLS regression in examining the influence of board structure, insider ownership on company performance. But there might remain a high fear of endogeneity effect on the OLS estimates. Therefore, it is no longer factual to interpret the OLS coefficients until we are checking endogeneity. Unlike OLS model, 2SLS regression can produce reliable coefficients controlling endogeneity. But there is a great concern about the validity of the instrumental variables included in 2SLS regression analysis since violation of this condition can lead to biased estimates. To test the validity of the instrumental variables, overidentification test is applied. Furthermore, Hausman test (Greene, 2003) is employed to check the reliability of the coefficient estimates of the OLS model compared to that of the 2SLS model. However, this study estimated the OLS and 2SLS coefficients, then endogeneity test, overidentification test, and Hausman test were performed. The Table 4 shows the results of endogeneity and overidentification tests. As it is observed in column (a) of Table 4, both Durbin and Wu-Hausman tests results strongly recognize board size as an endogenous variable since the null hypothesis that the variable is exogenous is rejected at 4 percent level of significance, while allowing for natural logarithm of sales and debt ratio as instrumental variables and ROA as dependent variable.

Table 4: Summary of Endogeneity, Overidentification and HausmanTests

\begin{tabular}{|c|c|c|c|}
\hline Dependent Variables & ROA & ROE & TBQ \\
\hline & (a) & (b) & (c) \\
\hline Test of Endogeneity : & \multicolumn{2}{|c|}{ Null hypothesis- Board size is exoneous } & \\
\hline Instrumental Variables & Lns and Tdta & Lns and Eown & Lns, Tdta and Eown \\
\hline Durbin chi-squared & $\begin{array}{c}4.95426^{* *} \\
(p=0.0260)\end{array}$ & $\begin{array}{c}4.59772^{* *} \\
(\mathrm{P}=0.0320)\end{array}$ & $\begin{array}{c}.119427 \\
(\mathrm{P}=0.7297)\end{array}$ \\
\hline
\end{tabular}


Business Review- A Journal of Business Administration Discipline, Khulna University, Volume: 15, Number: 1, January-December 2020, pp. 1-13 (Print ISSN: 1811-3788; Online ISSN: 2664-3502)

\begin{tabular}{lccc} 
Wu-Hausman & $4.7291^{* *}$ & $4.38287^{* *}$ & .110462 \\
F-statistic & $(\mathrm{p}=0.0306)$ & $(\mathrm{P}=0.0373)$ & $(\mathrm{P}=0.7400)$ \\
\hline Test of Overidentification: & Null hypothesis- Disturbance term & is not correlated with the instrumental variables. \\
Sargan chi-squared & .492167 & 1.16332 & 2.93897 \\
& $(\mathrm{P}=0.4830)$ & $(\mathrm{P}=0.2808)$ & $(\mathrm{P}=0.2300)$ \\
Basmann chi-squared & .462021 & 1.09479 & 2.73963 \\
& $(\mathrm{P}=0.4967)$ & $(\mathrm{P}=0.2954)$ & $(\mathrm{P}=0.2542)$ \\
\hline Hausman test: & Null hypothesis- OLS estimator is consistent & 0.12 \\
Hausman Chi-squared & 4.66 & 4.33 & $\mathrm{P}=0.7302$ \\
& $\mathrm{P}=0.0309$ & $\mathrm{P}=0.0376$ & \\
**, and $* * *$ represent $0.1,0.05$, and 0.01 level of significance respectively &
\end{tabular}

$*$, **, and $* * *$ represent $0.1,0.05$, and 0.01 level of significance respectively

The over identification test shows that p-value of Sargan chi-squared is 0.4830 and Basmann chi-squared is 0.4967 , indicating that the instrumental variables are exogenous and valid at 5 percent level of significance. The p-value of Hausman chi-squared shown in column (a) of Table 4 is 0.0309 , indicating that OLS estimator is consistent at least 5 percent significance level and, hence, it is providing support for using 2SLS estimator. Therefore, results of 2SLS are finally retained and presented in column (a) of Table 5 for further discussion in assessing the influence of board structure on ROA. Similarly, results of endogeneity test presented in column (b) of Table 4 confirm that board size is endogenous and, in addition, over identification test documents that instrumental variables are exogenous. These results imply that the 2SLS is correctly specified. Moreover, Hausman test shown in column (b) of Table 4 is statistically significant at 5 percent level, so this study rejected the null hypothesis. Thus, this study is predisposed to favor retaining 2SLS regression analysis over OLS regression, which is presented in column (b) of Table 5. Moreover, there is no statistical evidence to consider board size as endogenous for Tobin's Q though the instrumental variables of board size namely firm size, executive ownership, and debt ratio have satisfied the over identification tests. Apart from, OLS estimator is found significantly consistent at 5 percent level, shown in column (c) of Table 4. Therefore, OLS regression results are retained and presented in column (c) of Table 5 for further discussion in examining the effects of board structure, insider ownership on market based measure of performance i.e. TBQ.

Results of regression analysis: Satisfying endogeneity, over identification, and Hausman tests, Table 5 represents the findings of econometric analysis for assessing the effects of board structure, insider ownership on firm performance. The statistically significant value of F-statistic for all regression analyses confirms validity of the estimated models.

In Table 5, it is observed that performance measured in ROA and ROE is significantly and positively associated with the size of board, though TBQ is not significantly related to the size of board. Supporting agency theory, results imply that large board has good incentive to provide effective monitoring and lessen the managerial expropriation and, thus, improves performance of a firm. This significant positive association between these variables is parallel with the findings of Kiel and Nicholson (2003) and Karayel and Doğan (2016), though it is inconsistent with Rashid et al. (2010) in Bangladeshi context. The contradictory results might be caused by data characteristics and different methods used in this study. Hence, the proposed hypothesis that large board is advantageous to the firms to enhance their performance is partly supported.

Table 5: Summary of 2SLS and OLS regression analysis

Column (a), (b), and (c) show the coefficient estimates of performance measures. Parenthesis contains t-statistics.

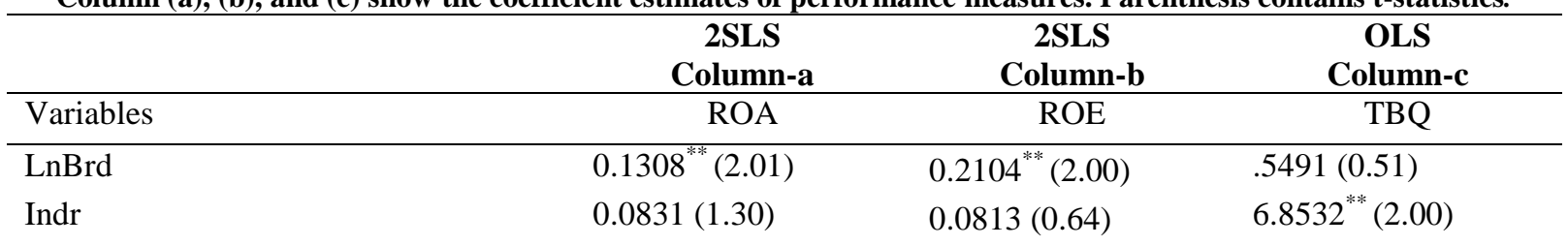


Business Review- A Journal of Business Administration Discipline, Khulna University, Volume: 15, Number: 1, January-December 2020, pp. 1-13 (Print ISSN: 1811-3788; Online ISSN: 2664-3502)

\begin{tabular}{|c|c|c|c|}
\hline Dual & $-0.0725^{* * *}(-3.63)$ & $-0.1433^{* * * *}(-3.60)$ & $-.5542(-0.47)$ \\
\hline InOwn & $0.1530^{* * *}(5.29)$ & $0.3367^{* * *}(6.02)$ & $3.1744^{* *}(2.25)$ \\
\hline Lev1 & $-0.0084(-1.17)$ & $\left.0.0430^{* * * *} 3.07\right)$ & $-.3129(-0.87)$ \\
\hline Lev2 & $-0.0691^{* * *}(-4.44)$ & $\left.-0.1444^{* * *}-4.60\right)$ & $-1.0684(-1.23)$ \\
\hline Age & $-0.0002(-0.34)$ & $-0.0003(-0.24)$ & $.0577^{* *}(2.20)$ \\
\hline Grow & $-0.0034(-0.20)$ & $-0.0009(-0.03)$ & $1.0374(1.11)$ \\
\hline Ceramics & $0.0105(0.35)$ & $0.0214(0.38)$ & $-1.637(-1.25)$ \\
\hline Engineering & $0.0297(1.40)$ & $0.0741^{*}(1.81)$ & $-5.0687^{* * * *}(-4.96)$ \\
\hline Food and Allied & $0.1660^{* * * *}(6.11)$ & $0.3786^{* * * * *}(7.44)$ & $-4.1725^{* * *}(-3.53)$ \\
\hline Fuel and Power & $0.0033(0.12)$ & $-0.0088(-0.17)$ & $-4.6327^{* * *}(-3.87)$ \\
\hline IT & $-0.0007(-0.03)$ & $0.0225(0.43)$ & $-4.4783^{* * *}(-3.40)$ \\
\hline Pharmaceuticals and Chemicals & $0.0830^{* * * * *}(3.83)$ & $0.1642^{* * * *}(3.86)$ & $-4.2006^{* * *}(-3.87)$ \\
\hline Textile & $0.0072(0.28)$ & $0.0234(0.50)$ & $-5.2585^{* * *}(-5.14)$ \\
\hline Constant & $-0.2480^{*}(-1.85)$ & $0.4732^{* * *}(-2.15)$ & $1.7021(0.66)$ \\
\hline F-Statistic & $14.08^{* * * *}$ & $15.91^{* * *}$ & $4.98^{* * *}$ \\
\hline Adjt. $\mathrm{R}^{2}$ & 0.3631 & 0.4218 & 0.2103 \\
\hline
\end{tabular}

In Table 5, observed results indicate that the coefficient values of board independence are positive for ROA and $\mathrm{ROE}$, though none of them is significant at 5 percent level. On the other hand, it is significantly and positively associated with TBQ, suggesting that the board comprising of more independent directors is highly capable to control managers' expropriating actions and minimize agency problem between control shareholders and minor shareholders. It also supports an argument that appointment of additional outside directors in the board signals a positive view to retail investors (Rosenstein and Wyatt, 1990). These results are in line with Kiel and Nicholson (2003) and Al-Msiedeen et al (2018) but not parallel to Rashid et al. (2010). These unparalleled finding is most likely due to preference of using different cross-sectional and time series observations. However, it may be argued that to strengthen the grip of independent directors on the board function BSEC's revised CGN in 2012 requiring listed firms to accommodate minimum 10 percent independent directors into board worked appropriately to provide the firm with effective monitoring role in protecting minor shareholders' interests, but might not assist and guide the company in increasing accounting profit. Therefore, the hypothesis that board independence is advantageous to the firms to enhance their performance is partly retained.

In Table 5, it is observed that CEO duality is significantly and negatively associated with ROA and ROE, though it is insignificantly associated with TBQ. Therefore, this evidence supports the view of agency theory that CEO duality is no more advantageous to the firm performance since it permits the board exposers to a threat of imbalance and permits a conflict (Dalton and Kesner, 1987; Tricker, 1994). This result is consistent with Doğan et al. (2013) and Blibech and Berraies, (2018). Thus, it provides a strong evidence to support a view that CEO duality could be blamed for poor performance in Bangladeshi listed companies.

Observed results in Table 5 indicate that insider ownership has good incentive to positively influence firm performance, implying that the high ownership creates a good incentive to align principals' interests with managers' interests, reduces information asymmetry between management and owners, makes the directors reluctant to expropriate firm wealth and, more importantly, directors of board practice good governance for the sake of their long term investment efficiency. This view is parallel with the findings of (Han and Suk, 1998; Mollah and Talukder, 2007; Lima and Hossain, 2018). As has been mentioned earlier, the BSEC issued a directive requiring the directors to hold at least 30 percent stake of equity in an attempt to normalize the movement of DSE index after the shock. Along the line, the findings of this study confirm the view of BSEC in protecting shareholders' interest and stabilizing market performances for the successive years. 
Business Review- A Journal of Business Administration Discipline, Khulna University, Volume: 15, Number: 1, January-December 2020, pp. 1-13 (Print ISSN: 1811-3788; Online ISSN: 2664-3502)

In addition, control variables are found significant in explaining firm performance. In this regard, it should however be mentioned that firm performance is significantly varies with industry settings.

\section{Summary and Conclusion}

The study was aimed at inspecting how both the board structure and insider ownership contribute as a mechanism of corporate governance systems towards the improvements of corporate performance after controlling for any possible spurious association between them. A key motivational perspective of this work was that how the governance directives/notifications issued by BSEC, came into effect in 2012, specially in regard to board independence and insider ownership that how they are being effective in protecting the shareholders' interest through enhancing firm performance during the post-shock period of stock prices in Bangladesh. The data of sample firms during the sixyear periods from 2013 to 2018 have been taken into account for running OLS and 2SLS regression models. In the process of getting a robust regression coefficient estimates the analysis satisfies endogeneity, over identification tests and Hausman tests.

Consistent with the agency theory, the findings imply that large boards are functioning well in the context of Bangladeshi firms; large board improves firm performance through widening the ability of a corporate board to supervise and monitor the managerial actions. In regard to the board independence, it is evident that market base measure of performance (TBQ) increases as the presence of independent directors rises. However, confirming the agency theory, significant coefficient value of board independence supports a view that compliance with corporate governance guidelines issued in 2012 has made noteworthy enhancements in firm performance. In connection with findings of CEO duality, it is suggested that a firm keeping its board chairman from occupying the position of chief executive experiences better performance. The results also provide support to a view that insider ownership can be a good instrument for controlling the agency problem as it builds up a bridge in the gap between principals' and agents' interests. Control variables are also found significant in affecting firm performance. More importantly, it is supporting a view that the financial performance of Bangladesh listed companies varies with industry settings.

These findings have some practical implications for regulatory bodies, policy makers, and corporate boards to develop effective corporate governance frameworks and mechanisms. As per observed results, it can be suggested that despite independent directors' insignificant roles in improving accounting performance, their roles are beyond the questions in improving market based performance and protecting retail investors' interests. Nonetheless, the board shall appoint the independent directors whose qualifications can be perfect complement to the ability of executive directors otherwise it would be a good for nothing to monitor and supervise managerial activities. The positive consequence of ownership concentration on performance is consistent with Rashid (2015) suggesting that a board with inside directors having substantial ownerships wields enormous capability to monitor managerial activities, becomes highly obliged to protect shareholders' wealth and has incentives to build a bonding relationship with the minor shareholders. Supporting the view of agency theory, it is empirically well justified to blame the CEO duality for poor corporate performance in Bangladesh. Now, on the edge of these discussions, it is evident that conforming to the directives/notifications issued by the BSEC following the collapse of DSE in 2011 brought in a great stand against further market crash and to stabilize market performance. Therefore, in formulating advanced reforms in corporate governance mechanisms in Bangladesh these movements deserve to be glorified and not be abandoned.

In conclusion, this study may not be free from shortcomings that lay the foundation for future work in the field of governance mechanisms. First, the demographic characteristics of corporate board i.e. age, qualifications, and experiences of directors may influence the association between governance mechanism and performance (Huse, 2005). Second, the study only taken into account insider ownership and, therefore, other definitions of ownership structure are left to be tested on different sample data. 
Business Review- A Journal of Business Administration Discipline, Khulna University, Volume: 15, Number: 1, January-December 2020, pp. 1-13 (Print ISSN: 1811-3788; Online ISSN: 2664-3502)

\section{References}

Adams, R.B. and Ferreira, D., 2007. A theory of friendly boards. Journal of Finance. 62(1), pp.217-250.

Adams, R. and Mehran, H., 2005. Corporate performance, board structure and its determinants in the banking industry. Working paper, Federal Reserve Bank of New York.

Agrawal, A. and Knoeber, C. R., 1996. Firm performance and mechanisms to control agency problems between managers and shareholders. Journal of Financial and Quantitative Analysis, 31(3), pp.377-97.

Al-Msiedeen, J. M., Rashid, A. and Shams, S., 2018. Board Independence and Firm Performance: Evidence from Jordan. Proceedings of Sydney International Business Research Conference 2018, Sydney, Australia, Australian Academy of Business Leadership, pp.105-121.

Baltagi, B.H., 2005. Econometric Analysis of Panel Data, John Wiley \& Sons Inc. New York, NY.

Bhagat, S. and Black, B., 2002. The non-correlation between board independence and long-term firm performance. Journal of Corporation Law, 27(2), pp.231-273.

Blibech, N. and Berraies, S., 2018. The impact of CEO' duality and board's size and independence on firms' innovation and financial performance. Journal of Business Management and Economics, 9(1), pp.022029.

Booth, J. and Deli, D., 1996. Factors affecting the number of outside directorships held by CEOs. Journal of Financial Economics, 40, pp.81-104.

Brennan, N., 2006. Boards of directors and firm performance: Is there an expectations gap? Corporate Governance: An International Review, 14(6), pp.577-593.

Carter, D.A., Simkins, B.J. and Simpson, W.G., 2003. Corporate governance, board diversity, and firm value. Financial Review, 38, pp.33-53.

Chaterjee, S. and Price, B., 1991. Regression Analysis by Example. John Wiley and Sons. New York, NY.

Chen, C.W., Lin, J.B. and Yi, B., 2008. CEO duality and firm performance: An endogenous issue. Corporate Ownership and Control, 6(1), pp.58-65.

Coles, J.L., Daniel, N.D. and Naveen, L., 2008. Boards: Does one size fit all? Journal of Financial Economics, 87, pp.329-356.

Daily, C.M. and Dalton, D.R., 1992. The relationship between governance structure and corporate performance in entrepreneurial firms. Journal of Business Venturing, 7(5), pp.375-386.

Daily, C.M. and Dalton, D.R., 1994. Bankruptcy and corporate governance: The impact of board composition and structure. Academy of Management Journal, 37, pp.1603-1617.

Dalton, D.R. and Kesner, I.F., 1987. Composition and CEO duality in boards of directors: An inter- national perspective. Journal of International Business Studies, 18(3), pp.33-42

Davis, J.H., Schoorman, F.D. and Donaldson, L., 1997. Towards a stewardship theory of management. Academy of Management Review, 22(1), pp.20-47.

Donaldson, L., 1990. The ethereal hand: organizational economics and management theory. Academy of Management Review, 15(3), pp.369-381.

Donaldson, L. and Davis, J.H., 1991. Stewardship theory or agency theory: CEO governance and shareholder returns. Australian Journal of Management, 16(1), pp.49-64.

Doğan, M., Elitaş, B.L., Ağca, V., and ÖGEL, S., 2013. The Impact of CEO Duality on Firm Performance: Evidence From Turkey. International Journal of Business and Social Science, 4(2), pp.149-155.

Fama, E.F. and Jensen, M.C., 1983. Separation of ownership and control. Journal of Law and Economics, 26, pp.301-325.

Fernandes, N., 2005. Board compensation and firm performance: the role of "independent" board members. ECGI Working Paper Series in Finance, European Corporate Governance Institute.

Finkelstein, S. and D'Aveni, R.A., 1994. CEO duality as a double-edged sword: How boards of directors balance entrenchment avoidance and unity of command. Academy of Management Journal, 37(5), pp.1079-1108.

Forbes, D. and Milliken, F., 1999. Cognition and corporate governance: Understanding boards of directors as strategic decision making groups. Academy of Management Review, 24, pp.489- 505.

Greene, W.H., 2003. Econometric Analysis. Pearson Education Inc. New Jersey. 
Business Review- A Journal of Business Administration Discipline, Khulna University, Volume: 15, Number: 1, January-December 2020, pp. 1-13 (Print ISSN: 1811-3788; Online ISSN: 2664-3502)

Han, K.C., and Suk, D.Y., 1998. The effect of ownership structure on firm performance: additional evidence. Review of Financial Economics, 7(2), pp.143-55.

Hasan, A. and Butt, S.A., 2009. Impact of ownership structure and corporate governance on capital structure of Pakistani listed companies. International Journal of Business and Management, 4(2), pp.50-57.

Hermalin, B.E. and Weisbach, M.S., 2003. Board of directors as an endogenously determined institution: A survey of the economic literature. Economic Policy Review, 9(1), pp.7-26.

Huse, M., 2005. Accountability and creating accountability: A framework for exploring behavioural perspectives of corporate governance. British Journal of Management, 16, pp.65-79.

Jensen, M.C., 1993. The modern industrial revolution, exit, and the failure of internal control systems. Journal of Finance, 48(3), pp.831-880.

Jensen, M.C., and Meckling, W.H., 1976. Theory of the firm: Managerial behavior, agency costs and ownership structure. Journal of Financial Economics, 3, pp.305-360.

Johnson, J., Daily, L., and Ellstrand, A., 1996. Board of Directors: A Review and Research Agenda. Journal of Management, 22, pp.409-438.

Kalsie, A. and Shrivastav, S.M., 2016. Analysis of board size and firm performance: Evidence from NSE companies using panel data approach. Indian Journal of Corporate Governance, 9(2), pp.148-172.

Karayel, M. and Doğan, M., 2016. Board composition and firm performance: Evidence from BIST 100 companies in Turkey. Economics and Applied Informatics, 2, pp.33-40

Kiel, G.C. and Nicholson, G.J., 2003. Board composition and corporate performance: How the Australian experience informs contrasting theories of corporate governance. Corporate Governance: An International Review, 11(3), pp.189 - 205.

Leblanc, R.W., 2004. What's wrong with corporate governance: A note. Corporate Governance: An International Review, 12(4), pp.436- 441.

Lima, M., and Hossain, I., 2018. Ownership Structure and Firm Performance: Testing Monitoring and Expropriation Hypotheses for Bangladeshi Companies. Journal of Finance and Banking, 14(1-2). [Online] Available at: <https://www.researchgate.net/publication/329644494_Ownership_Structure_and_Firm_Performance_Test ing_Monitoring_and_Expropriation_Hypotheses_for_Bangladeshi_Companies> [Accessed 11 December 2019]

Liu, Y., Miletkov, M.K., Weia, Z., and Yang, T., 2015. Board independence and firm performance in China. Journal of Corporate Finance, 30, pp.223-244.

MoIlah, A.S. and Talukdar, M.B., 2007. Ownership structure, corporate governance, and firm's performance in emerging markets: Evidence from Bangladesh. The International Journal of Finance, 19(1), pp.4315-4333.

Pfeffer, J., 1972. Size and composition of corporate boards of directors: The organization and its environment. Administrative Science Quarterly, 17, pp.218-228.

Rashid, A., 2009. Board composition, board leadership structure and firm performance: Evidence from Bangladesh. The Accounting and Finance Association of Australia and New Zealand (AFAANZ) Annual Conference, 57th July, Adelaide, South Australia.

Rashid, A., 2015. Revisiting agency theory: Evidence of board independence and agency cost from Bangladesh. Journal of Business Ethics, 130(1), pp.181-198.

Rashid, A., Zoysa, A.D., Lodh, S. and Rudkin, K., 2010. Board composition and firm performance: Evidence from Bangladesh. Australasian Accounting Business and Finance Journal, 4(10), pp.76-95.

Rose, C., 2005. The composition of semi-two tier corporate boards and firm performance. Corporate Governance: An International Review, 13(5), pp.691- 701.

Rosenstein, S. and Wyatt, J.G., 1990. Outside directors, board independence, and shareholder wealth. Journal of Financial Economics, 26(2), pp.175-191.

Tricker, R., 1994. International Corporate Governance. Prentice-Hall. Singapore.

Wahla, K., Shah, S. and Hussain, Z., 2012. Impact of ownership structure on firm performance: Evidence from nonfinancial listed companies at Karachi Stock Exchange. International Research Journal of Finance and Economics, 84, pp.6-13. 
Wan, D. and Ong, C.H., 2005. Board structure, process and performance: Evidence from public listed companies in Singapore. Corporate Governance: An International Review, 13(2), pp.277-290.

Weidenbaum, M.L., 1986. Updating the corporate board. Journal of Business Strategy, 7, pp.77-83.

Yermack, D., 1996. Higher market valuation of companies with a small board of directors. Journal of Financial Economics, 40(2), pp.185-211.

Zahra, S.A. and Pearce II. J.A., 1989. Board of directors and corporate financial performance: A review and integrative model. Journal of Management, 15(2), pp.291-334. 